\title{
Organic-walled microfossils and palynodebris in cold seep carbonate deposits: The Upper Jurassic-Lower Cretaceous Agardhfjellet Formation on Svalbard (Arctic Norway)
}

\author{
Thine Sanne Dalseg ${ }^{1}$, Hans Arne Nakrem² \& Morten Smelror ${ }^{3}$ \\ ${ }^{1}$ BakerHughes, Tanangerveien 501, NO-4056 Tananger, Norway. \\ ${ }^{2}$ Natural History Museum, University of Oslo, P.O. Box 1172 Blindern, NO-0318 Oslo, Norway. \\ ${ }^{3}$ Geological survey of Norway, P.O. Box 6215 Sluppen, NO-7491 Trondheim, Norway.
}

E-mail corresponding author (Thine Sanne Dalseg): thinesd@gmail.com

This study gives the first detailed report of palynomorphs from Mesozoic cold hydrocarbon seep deposits. The organic-walled microfossils and palynodebris comprise ex situ fossil material in the seep deposits of the Upper Jurassic-Lower Cretaceous Agardhfjellet Formation, and consist of both specimens that originated during the time of deposition and a few fossils reworked from older strata. The palynomorphs from the Agardhfjellet Formation carbonate seep deposits in Central Spitsbergen, Svalbard, are better preserved than the palynological material in the shale deposits in the same formation. This is due to early authigenic precipitation of carbonate, which led to a relatively rapid cementation of the sediments, preventing flattening of the fossils. The Non-metric Multidimensional Scaling (NMDS) of the dinoflagellate cyst assemblages in the studied succession shows an age-specific trend, rather than being environmentally controlled, while the NMDS of the palynofacies shows that the content of palynodebris in the samples is more environmental-specific than age-specific.

Keywords: Mesozoic, seeps, carbonates, palynomorphs, palynofacies, Svalbard, Arctic

Received 16. November 2015 / Accepted 20. February 2016 / Published 19. May 2016

\section{Introduction}

Cold hydrocarbon seeps occur in geologically active and passive continental margins, where pore waters enriched in methane are forced upward through the sediments by pressure gradients. Cold seep habitats were practically unknown to science prior to the first records on the Florida Escarpment in the Gulf of Mexico some 30 years ago (Paull et al., 1984). More recently, such special marine environments have been documented in a broad range of tectonic settings around the world's seas (Campbell et al., 2002; Levin, 2005; Campbell, 2006), including the margins of the Norwegian Sea and Barents Sea (Hovland
\& Svendsen, 2006; Chand et al., 2008, 2012; Berndt et al., 2014). There are examples of extant carbonates associated with both hydrate (primarily methane-bearing hydrate) melting and sea-floor hydrocarbon seeps (Ritger et al., 1987; Sassen et al., 1993; MacDonald et al., 1994; Naehr et al., 2000). These include several unequivocal analogues recognised in the Mesozoic rock record (Beauchamp \& Savard, 1992; Kelly et al., 1995; Kauffman et al., 1996; Kiel et al., 2008).

Methane seeps at the sea bottom are generally associated with complex and rich ecosystems, where the high concentrations of methane and sulphide passing through

Dalseg, T.S., Nakrem, H.A. \& Smelror, M. 2016: Organic-walled microfossils and palynodebris in cold seep carbonate deposits: The Upper Jurassic-Lower Cretaceous Agardhfjellet Formation on Svalbard (Arctic Norway). Norwegian Journal of Geology 96, 135-146. http://dx.doi. org/10.17850/njg96-2-01. 


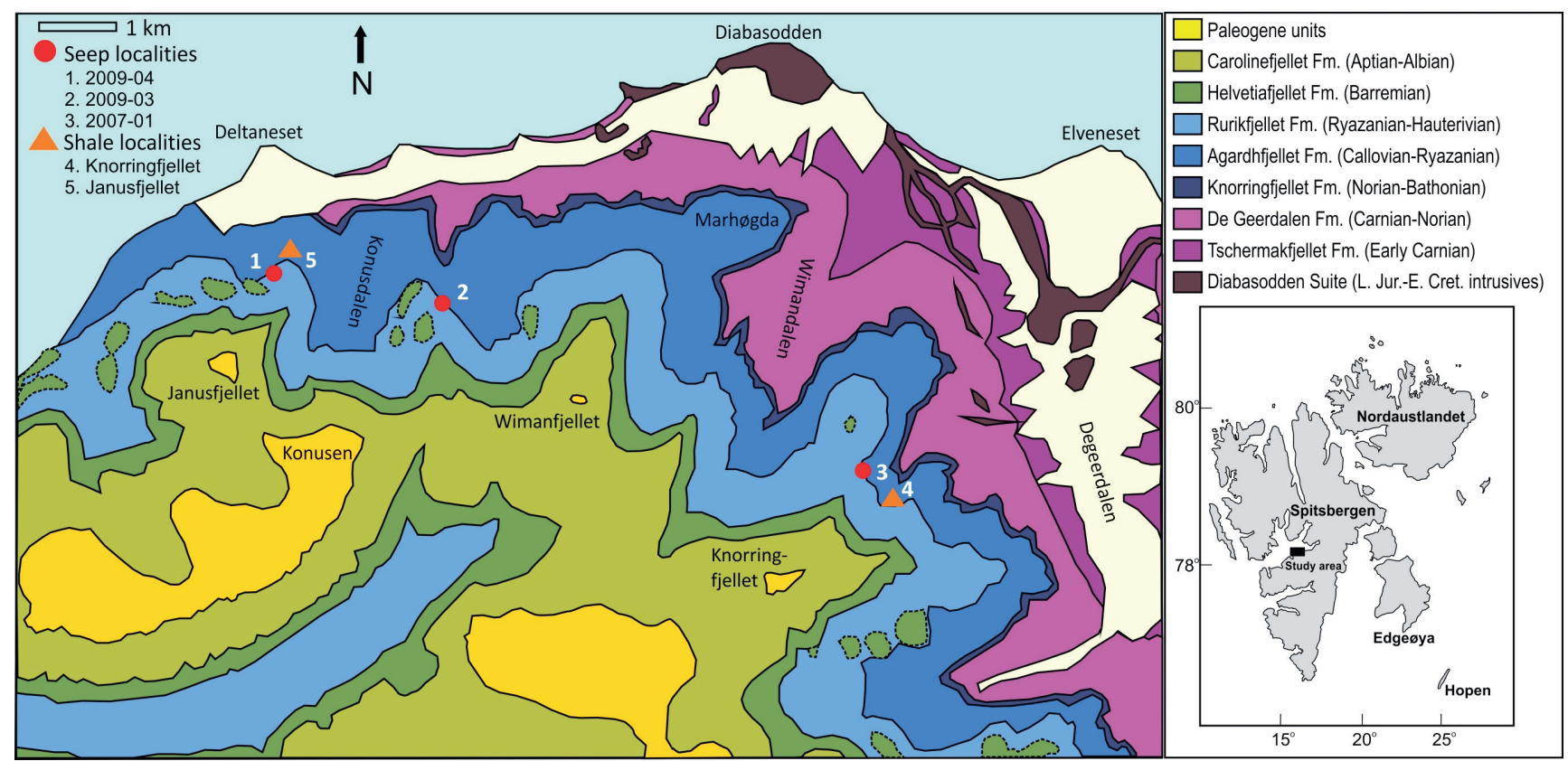

Figure 1. Geological map of the study area and seep localities with inset map of Svalbard showing the location of the study area (modified from Dallmann et al., 2001).

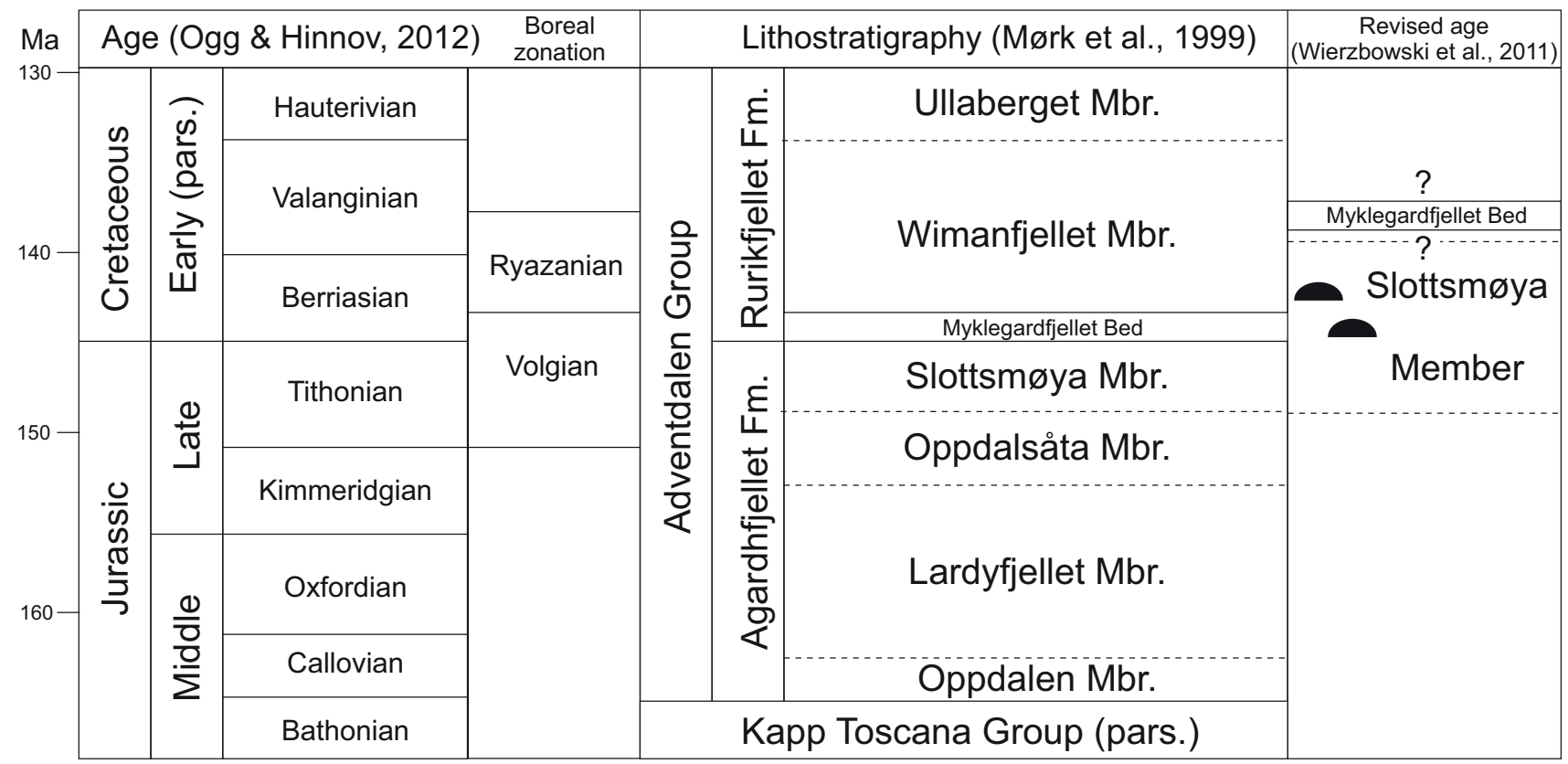

Figure 2. Lithostratigraphic subdivision of the Middle Jurassic-Lower Cretaceous succession on Svalbard. The column to the right shows the revised age of the Slottsmøya Member and Myklegardfjellet Bed as determined by Wierzbowski et al. (2011).

the vents provide nutrients to abundant free-living and symbiotic bacteria, resulting in increased food supplies. In such environments, anaerobic methane oxidation presumably coupled to sulphate reduction leads to formation of carbonates, providing a hard substratum for specialised benthic communities of protozoan and metazoan faunas. The faunal biomass at seeps generally far exceeds that of surrounding non-seep sediments and is often dominated by bivalves, tube-worms, brachiopods, echinoderms, sponges and gastropods (Levin, 2005). In addition, shrimps, crabs and bottom-dwelling fish may be common in the seep communities.

The present study concerns organic-walled microfossils (palynomorphs) and organic sedimentary particles (palynofacies) found in shales and carbonate seep deposits in the Upper Jurassic - Lower Cretaceous Agardhfjellet Formation (Slottsmøya Member) in the Sassenfjorden area of Spitsbergen (Svalbard) (Figs. 1, 2; Tables 1-3). The organic-walled microfossils and palynodebris analysed in 


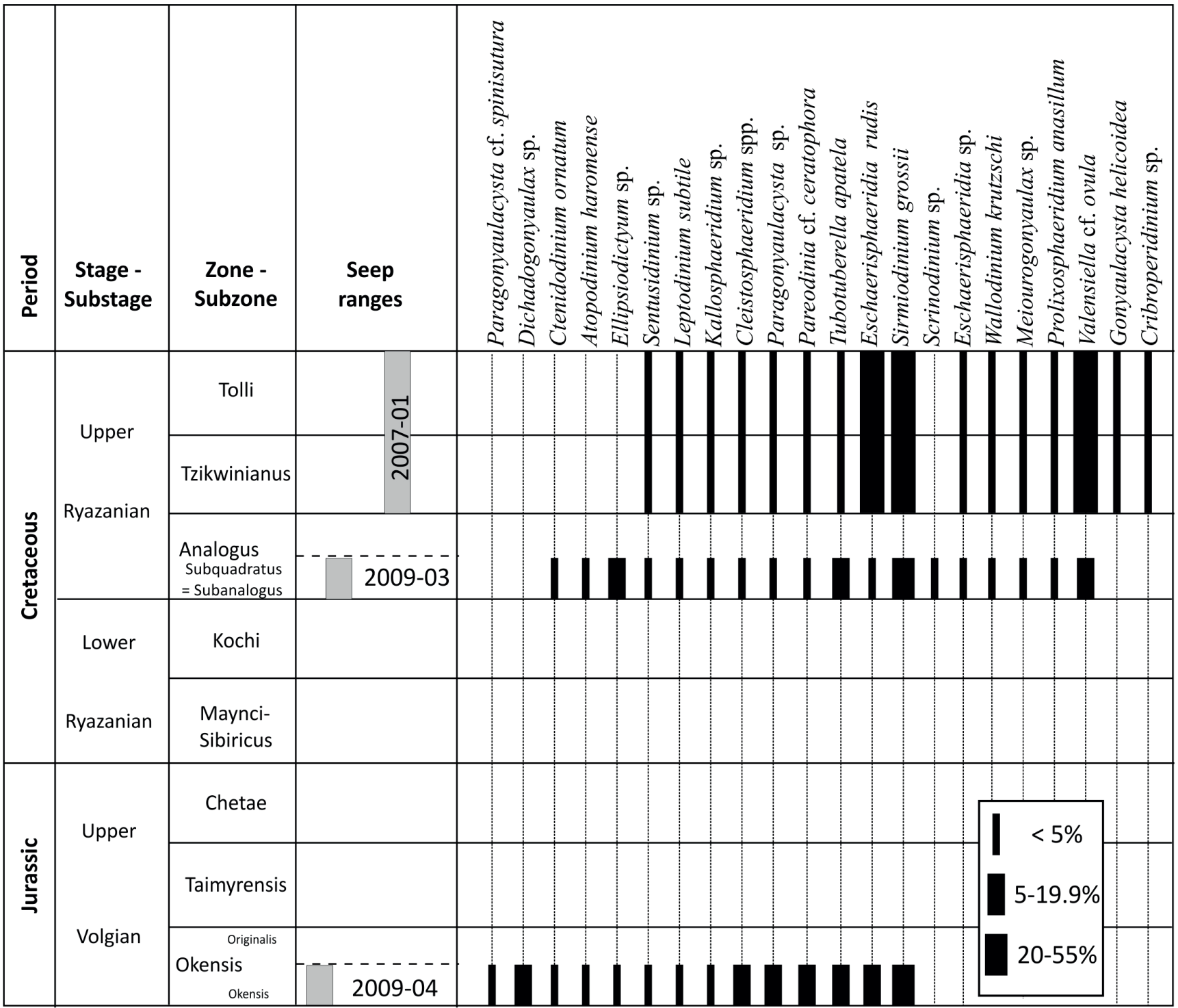

Figure 3. Ammonite zones established by Wierzbowski et al. (2011) and the recorded occurrences of dinoflagellate cyst taxa in seep samples 2009-04, 2009-03 and 2007-01.

the present study comprise ex situ fossil material in the seep deposits. The palynomorphs consist of both specimens that originated during the time of deposition and a few fossils reworked from older strata (Fig. 3). The sedimentary facies, stable isotope analyses and fossil faunas in these seep deposits have previously been well documented by Hammer et al. $(2011,2012,2013)$, Wierzbowski et al. (2011), Hjálmarsdóttir et al. (2012), Hryniewicz et al. $(2012,2014,2015)$ and Sandy et al. (2014).

\section{Material and methods}

Three samples from cold methane seep deposits in the Slottsmøya Member (Agardhfjellet Formation) were included in the study (Fig. 3, Table 3). The samples were collected by Øyvind Hammer and Hans Arne Nakrem during the palaeontological expeditions conducted by the Natural History Museum, University of Oslo, in 2007 and 2009. Two of the seep samples were collected at Janusfjellet (2009-03 and 2009-04) and one was collected at Knorringfjellet (2007-01) (Fig. 1). All the seeps are located above the Dorsoplanites bed, i.e., above $27 \mathrm{~m}$ in the profile presented by Collignon (2011). Samples 2007-01 from Knorringfjellet and 2009-03 from Janusfiellet are of Ryazanian age, while sample 2009-4 from Janusfellet is of Late Volgian age (Fig. 2; Wierzbowski et al., 2011; Hjálmarsdóttir et al., 2012). The largest seep carbonate body (2007-01) is measured to be $5 \mathrm{~m}$ in diameter, but its lateral extent may be greater in view of spreading of material down-slope due to frost wedging (Hammer et al., 2011).

Twenty shale samples were collected from the Janusfjellet profile, and 17 from the Knorring profile. 
Table 1. Palynofacies components (\%) in the analysed shale samples from Janusfjellet.

\begin{tabular}{|c|c|c|c|c|c|c|c|c|c|c|c|c|c|}
\hline Level (m) & CFTL & $\begin{array}{c}\mathrm{Bi} / \\
\text { monosaccate } \\
\text { pollen }\end{array}$ & $\begin{array}{l}\text { Reg. } \\
\text { pollen }\end{array}$ & Spores & Dinocysts & Tasmanites & $\begin{array}{c}\text { Leio- } \\
\text { sphaeridia }\end{array}$ & $\begin{array}{l}\text { Plant } \\
\text { debris }\end{array}$ & Wood & $\begin{array}{c}\text { AOM } \\
\text { total }\end{array}$ & $\begin{array}{l}\text { AOM } \\
\text { trans- } \\
\text { parent }\end{array}$ & $\begin{array}{c}\text { AOM } \\
\text { orange/ } \\
\text { yellow }\end{array}$ & $\begin{array}{l}\text { AOM } \\
\text { black/ } \\
\text { brown }\end{array}$ \\
\hline 45.62 & 0.0 & 0.3 & 0.7 & 4.7 & 0.3 & 0.0 & 28.1 & 11.7 & 0.0 & 54.2 & 1.3 & 26.4 & 26.4 \\
\hline 43.91 & 2.6 & 1.0 & 4.6 & 9.8 & 4.6 & 0.0 & 8.2 & 20.0 & 0.3 & 48.9 & 7.9 & 13.8 & 27.2 \\
\hline 42.13 & 0.0 & 0.3 & 3.7 & 8.0 & 5.3 & 0.3 & 13.3 & 12.7 & 0.0 & 56.3 & 1.3 & 21.7 & 33.3 \\
\hline 39.52 & 0.0 & 1.4 & 4.0 & 7.5 & 1.2 & 0.6 & 5.8 & 9.2 & 0.0 & 70.3 & 0.3 & 16.7 & 53.3 \\
\hline 36.71 & 1.2 & 0.0 & 4.0 & 6.8 & 0.9 & 0.3 & 10.5 & 12.1 & 0.0 & 64.1 & 0.6 & 14.2 & 49.2 \\
\hline 33.53 & 1.6 & 0.0 & 3.2 & 4.2 & 4.2 & 0.0 & 9.3 & 20.4 & 0.0 & 57.2 & 2.6 & 19.2 & 35.5 \\
\hline 30.00 & 0.7 & 0.7 & 3.9 & 4.3 & 5.6 & 0.7 & 2.3 & 33.4 & 0.3 & 48.2 & 2.0 & 8.9 & 37.4 \\
\hline 28.20 & 0.3 & 0.3 & 4.2 & 5.9 & 6.2 & 0.7 & 4.9 & 14.1 & 0.0 & 63.4 & 5.2 & 12.1 & 46.1 \\
\hline 26.07 & 1.6 & 0.3 & 1.9 & 10.4 & 4.7 & 1.3 & 3.2 & 20.8 & 0.0 & 55.8 & 4.1 & 13.2 & 38.5 \\
\hline 23.48 & 0.7 & 0.0 & 0.7 & 10.6 & 5.3 & 15.9 & 2.7 & 18.6 & 0.3 & 45.2 & 6.6 & 8.3 & 30.2 \\
\hline 20.94 & 0.9 & 0.0 & 1.2 & 15.5 & 5.0 & 1.6 & 0.6 & 21.7 & 0.0 & 53.4 & 1.6 & 2.5 & 49.4 \\
\hline 17.95 & 0.3 & 0.3 & 4.5 & 10.4 & 5.9 & 0.0 & 0.3 & 18.7 & 0.0 & 59.6 & 2.1 & 11.9 & 45.7 \\
\hline 15.77 & 0.3 & 0.0 & 5.5 & 10.2 & 6.5 & 0.3 & 1.5 & 28.6 & 0.9 & 46.2 & 4.0 & 3.1 & 39.1 \\
\hline 13.75 & 0.0 & 0.3 & 2.9 & 4.2 & 3.6 & 0.0 & 0.3 & 22.2 & 0.3 & 66.0 & 3.3 & 15.0 & 47.7 \\
\hline 10.89 & 0.0 & 1.0 & 4.1 & 6.2 & 3.4 & 0.0 & 0.0 & 27.2 & 1.0 & 56.9 & 3.4 & 18.6 & 34.8 \\
\hline 8.37 & 0.3 & 0.7 & 6.5 & 5.6 & 2.3 & 0.7 & 1.6 & 20.6 & 0.3 & 61.4 & 6.2 & 18.3 & 36.9 \\
\hline 6.03 & 0.3 & 0.7 & 2.7 & 6.3 & 4.7 & 1.3 & 0.0 & 35.2 & 0.3 & 48.5 & 12.6 & 20.6 & 15.3 \\
\hline 3.95 & 0.6 & 0.9 & 4.4 & 7.2 & 4.7 & 0.0 & 0.9 & 51.6 & 1.6 & 28.1 & 15.3 & 3.8 & 9.1 \\
\hline 0.77 & 0.3 & 0.3 & 1.6 & 6.2 & 14.0 & 0.0 & 0.0 & 35.1 & 0.6 & 41.9 & 5.3 & 12.1 & 24.5 \\
\hline-1.31 & 0.9 & 0.3 & 3.7 & 6.2 & 3.1 & 0.0 & 0.3 & 45.7 & 0.0 & 39.8 & 6.8 & 4.7 & 28.3 \\
\hline
\end{tabular}

$\mathrm{AOM}=$ amorphous organic matter; $\mathrm{CFTL}=$ chitinous foraminiferal test linings.

Table 2. Palynofacies components (\%) in the analysed shale samples from Knorringfjellet.

\begin{tabular}{|c|c|c|c|c|c|c|c|c|c|c|c|c|c|}
\hline Level $(m)$ & CFTL & $\begin{array}{c}\text { Bi/ } \\
\text { monosaccate } \\
\text { pollen }\end{array}$ & $\begin{array}{l}\text { Reg. } \\
\text { pollen }\end{array}$ & Spores & Dinocysts & Tasmanites & $\begin{array}{c}\text { Leio- } \\
\text { sphaeridia }\end{array}$ & $\begin{array}{l}\text { Plant } \\
\text { debris }\end{array}$ & Wood & $\begin{array}{c}A O M \\
\text { total }\end{array}$ & $\begin{array}{l}\text { AOM } \\
\text { trans- } \\
\text { parent }\end{array}$ & $\begin{array}{c}\text { AOM } \\
\text { orange/ } \\
\text { yellow }\end{array}$ & $\begin{array}{l}\text { AOM } \\
\text { black/ } \\
\text { brown }\end{array}$ \\
\hline 41.0 & 0.0 & 1.3 & 6.5 & 6.8 & 15.9 & 0.0 & 3.2 & 48.9 & 0.0 & 17.5 & 0.0 & 3.2 & 14.2 \\
\hline 36.0 & 0.0 & 2.3 & 2.6 & 1.6 & 7.4 & 0.0 & 0.3 & 39.0 & 0.6 & 46.1 & 0.3 & 13.2 & 32.6 \\
\hline 31.0 & 0.7 & 1.7 & 3.3 & 3.3 & 1.7 & 0.0 & 0.0 & 40.5 & 0.0 & 48.8 & 1.7 & 1.7 & 45.5 \\
\hline 26.0 & 0.0 & 0.0 & 3.2 & 1.0 & 3.2 & 0.0 & 0.0 & 55.8 & 1.3 & 35.6 & 4.5 & 14.7 & 16.3 \\
\hline 21.0 & 0.0 & 0.6 & 2.5 & 5.2 & 4.0 & 0.9 & 0.6 & 48.8 & 0.0 & 37.4 & 8.9 & 19.0 & 9.5 \\
\hline 16.0 & 0.0 & 1.0 & 5.0 & 4.7 & 8.4 & 0.0 & 0.3 & 53.7 & 3.0 & 23.8 & 1.3 & 0.7 & 21.8 \\
\hline 11.0 & 0.3 & 1.0 & 4.8 & 2.9 & 6.8 & 1.0 & 0.3 & 32.2 & 0.6 & 50.2 & 2.3 & 10.3 & 37.6 \\
\hline 6.0 & 0.0 & 0.0 & 4.0 & 3.1 & 3.4 & 0.9 & 0.3 & 36.4 & 0.9 & 50.9 & 1.5 & 7.1 & 42.3 \\
\hline 0.0 & 0.9 & 1.6 & 5.3 & 6.8 & 9.6 & 0.3 & 0.6 & 54.3 & 0.6 & 19.9 & 1.9 & 2.5 & 15.5 \\
\hline-2.0 & 0.7 & 0.3 & 2.0 & 4.7 & 3.0 & 0.0 & 0.3 & 54.3 & 4.3 & 30.3 & 0.7 & 10.0 & 19.7 \\
\hline-7.0 & 0.3 & 0.6 & 3.8 & 3.8 & 9.6 & 0.0 & 0.3 & 60.6 & 1.9 & 18.9 & 0.3 & 2.9 & 15.7 \\
\hline-11.0 & 1.0 & 0.3 & 4.0 & 4.3 & 9.0 & 0.0 & 0.0 & 61.7 & 3.3 & 16.3 & 1.0 & 3.7 & 11.7 \\
\hline-17.0 & 0.0 & 0.3 & 4.3 & 4.3 & 9.5 & 0.0 & 0.3 & 61.8 & 1.6 & 17.8 & 1.6 & 2.0 & 14.1 \\
\hline-21.0 & 1.0 & 1.6 & 9.7 & 7.4 & 4.5 & 0.0 & 1.3 & 64.8 & 4.2 & 5.5 & 0.6 & 1.6 & 3.2 \\
\hline-27.0 & 0.6 & 0.3 & 1.9 & 3.9 & 1.6 & 0.0 & 0.0 & 63.4 & 24.6 & 3.6 & 1.3 & 2.3 & 0.0 \\
\hline-29.0 & 0.0 & 0.0 & 2.9 & 4.9 & 5.8 & 0.0 & 0.3 & 63.6 & 19.2 & 3.2 & 0.3 & 1.3 & 1.6 \\
\hline-43.0 & 0.3 & 0.3 & 5.4 & 8.0 & 2.5 & 0.0 & 1.6 & 56.1 & 12.7 & 13.1 & 2.2 & 1.3 & 9.6 \\
\hline
\end{tabular}

$\mathrm{AOM}=$ amorphous organic matter; $\mathrm{CFTL}=$ chitinous foraminiferal test linings. 
Table 3. Palynofacies components (\%) in the analysed seep samples 2009-04 and 2009-03 from Knorringfjellet and 2007-01 from Janusfjellet.

\begin{tabular}{|c|c|c|c|c|c|c|c|c|c|c|c|c|c|}
\hline SEEP & CFTL & $\begin{array}{c}\mathrm{Bi} / \\
\text { monosaccate } \\
\text { pollen }\end{array}$ & Reg.pollen & Spores & Dinocysts & Tasmanites & $\begin{array}{c}\text { Leio- } \\
\text { sphaeridia }\end{array}$ & $\begin{array}{l}\text { Plant } \\
\text { debris }\end{array}$ & Wood & $\begin{array}{c}\text { AOM } \\
\text { (total) }\end{array}$ & $\begin{array}{l}\text { AOM } \\
\text { trans- } \\
\text { parent }\end{array}$ & $\begin{array}{c}\text { AOM } \\
\text { orange/ } \\
\text { yellow }\end{array}$ & $\begin{array}{l}\text { AOM } \\
\text { black/ } \\
\text { brown }\end{array}$ \\
\hline 2007-1 & 0.0 & 9.3 & 9.6 & 5.6 & 6.9 & 0 & 0 & 46.1 & 5.3 & 16.9 & 5.98 & 1.0 & 9.9 \\
\hline 2009-3 & 0.9 & 2.3 & 2.9 & 2.6 & 7.5 & 0 & 0 & 73.6 & 0.6 & 9.2 & 1.32 & 0.0 & 7.8 \\
\hline $2009-4$ & 0.0 & 2.3 & 2.9 & 5.5 & 9.3 & 0 & 0 & 38.9 & 3.7 & 37.2 & 3.78 & 3.2 & 30.2 \\
\hline
\end{tabular}

$\mathrm{AOM}=$ amorphous organic matter; $\mathrm{CFTL}=$ chitinous foraminiferal test linings.

The samples were processed by Applied Petroleum Technology AS, following standard palynological preparation procedures.

All the data from the palynological samples from the Upper Jurassic-Lower Cretaceous Agardhfjellet Formation were processed using Microsoft Excel and PAST (PAlaeontological STatistics) (Hammer et al., 2001). The similarity test is used to compare the palynofacies contents and the dinoflagellate cyst assemblages in three different sample sets: 1) Samples from Janusfjellet, 2) Samples from Knorringfiellet, and 3) Seep samples from both locations. The Non-metric Multidimensional Scaling (NMDS) method is used for reducing the dimensionality of the data. It is based on a similarity measure and attempts to retain as much of the relative ordering of distances between pairs of samples as possible. The axes in a NMDS plot do not have a particular meaning, only the relative positions of the NMDS scatter plot (Hammer et al., 2001).

\section{Upper Jurassic-Lower Cretaceous seep deposits in the Agardhfjellet Formation}

Several carbonate bodies formed from hydrocarbon seepage are found in the Upper Jurassic-Lower Cretaceous Slottsmøya Member of the Agardhfjellet Formation in the Sassenfjorden area in Central Spitsbergen, Svalbard (Fig. 2). The Agardhfjellet Formation consists dominantly of dark shale with minor siltstone and sandstone beds. In the Slottsmøya Member 15 seep carbonate bodies are found along c. $10 \mathrm{~km}$ of strike (Hammer et al., 2011). All the seep bodies are found at a similar stratigraphic level 5-11 m below the top of the member except one, which has slumped downhill. The carbonate deposits are heterogeneous in structure, and include zoned (botryoidal) cement textures and fissure-infilling sparite. Stable isotope analyses show highly negative $\delta^{13 \mathrm{C}}$ values (down to c. $-43 \%$ VPDB) in the zoned carbonate cements, consistent with authigenic precipitation in a hydrocarbon-rich environment (Hammer et al., 2011).

The Agardhfjellet Formation was deposited on a shelf in a generally low-energy regime, and under oxygen-deficient conditions (Dypvik et al., 1991a; Hryniewicz et al.,
2012). Collignon \& Hammer (2012) provided detailed lithostratigraphy and sedimentology of the Slottsmøya Member at Janusfellet, with lithostratigraphic, mineralogical, chemical and magnetic susceptibility logs. Their high-resolution stratigraphy was used as a reference framework for other stratigraphic, sedimentological and palaeontological studies covering the same succession (Hurum et al., 2012 and references therein). Further, the stratigraphy of the Slottsmøya Member is constrained by analysis of the organic carbon isotope chemostratigraphy and cyclostratigraphy by Hammer et al. (2012), who presented $\delta^{13 \mathrm{C}}$ org curves from three sections at Janusfellet and Knorringfjellet. According to Hammer et al. (2012) there are indications of a c. 400 kyr periodicity, which can be interpreted as a result of orbital forcing (long eccentricity).

The well preserved ammonites found in the seep carbonates provide a good tool for age determinations of seep deposits (Wierzbowski et al., 2011), and the recovered taxa have biostratigraphic ranges through the Upper Volgian Substage to the Upper Ryazanian. The foraminifera assemblages suggest a Late Volgian-Ryazanan age for the seep deposits (Nagy \& Basov, 1998; Hjálmarsdóttir et al., 2012).

The hydrocarbon served as a nutrient for chemoautotrophic microorganisms and was also instrumental in the formation of a hard substrate, which allowed sessile organisms to settle. Forming small, local hard-grounds, the seep carbonates in the Sassenfjorden area contain more common benthic fossils than the surrounding mudstones (Hammer et al., 2011). The carbonate seep deposits contain rich and well-preserved faunas, with bivalves, rhynchonelliform and lingulid brachiopods, gastropods, echinoderms, sponges, and serpulid and probable vestimentiferan worm tubes (Hammer et al., 2011; Wierzbowski et al., 2011; Hjálmarsdóttir et al., 2012; Holmer \& Nakrem, 2012; Sandy et al., 2014; Hryniewicz et al., 2015). The seep fauna contains few, if any, seep obligate taxa, consistent with formation in a relatively shallowwater palaeoenvironment (Hryniewicz et al., 2015).

Ammonites and microfacies in the three carbonate seep deposits in the Slottsmøya Member, from which the samples used in the present study were taken, have previously been described by Wierzbowski et al. (2011) and Hryniewicz et al. (2012), respectively. The carbon- 
ate samples used for the present palynological study have also been used to study foraminiferal assemblages (Hjálmarsdóttir et al., 2012).

\section{Correlation of dinoflagellate cyst occurrences in the seeps and the shales (NMDS)}

The compositions of dinoflagellate cyst assemblages from the Slottsmøya Member at Janusfjellet and Knorringsfjellet are shown in Figs. 4 and 5, respectively. The record- ed occurrences of dinoflagellate cyst taxa in the seep samples 2009-04, 2009-03 and 2007-01 from the Slottsmøya Member are shown in Fig. 3. All three samples from the carbonate seep deposits contain abundant and well preserved palynomorphs and palynodebris.

The Non-metric Multidimensional Scaling (NMDS) of the dinoflagellate cyst assemblages in the studied succession shows an age-specific trend, with higher stratigraphic levels towards the right in the graph (Fig. 6). The upper samples seem to cluster more than the lower samples. The seep samples show a more age-specific trend in the NMDS of the dinoflagellate cyst assemblages than in the NMDS of the palynofacies (Fig. 7).

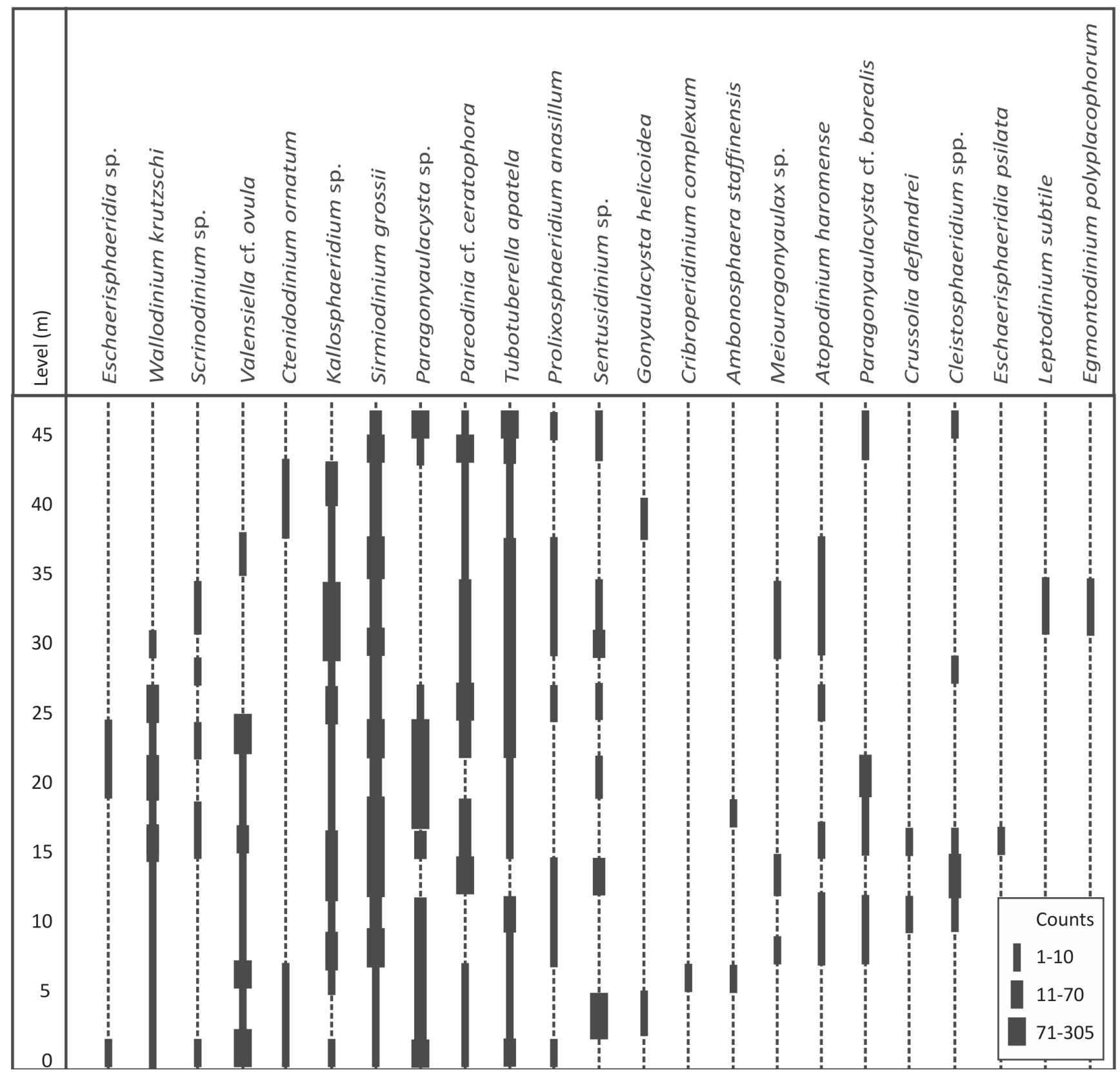

Figure 4. Stratigraphic and semi-quantitative distribution of dinoflagellate cyst taxa in the Slottsmøya Member at Janusfjellet, Central Spitsbergen. The diagram is based on counts of approximately 300 specimens for most of the samples. 


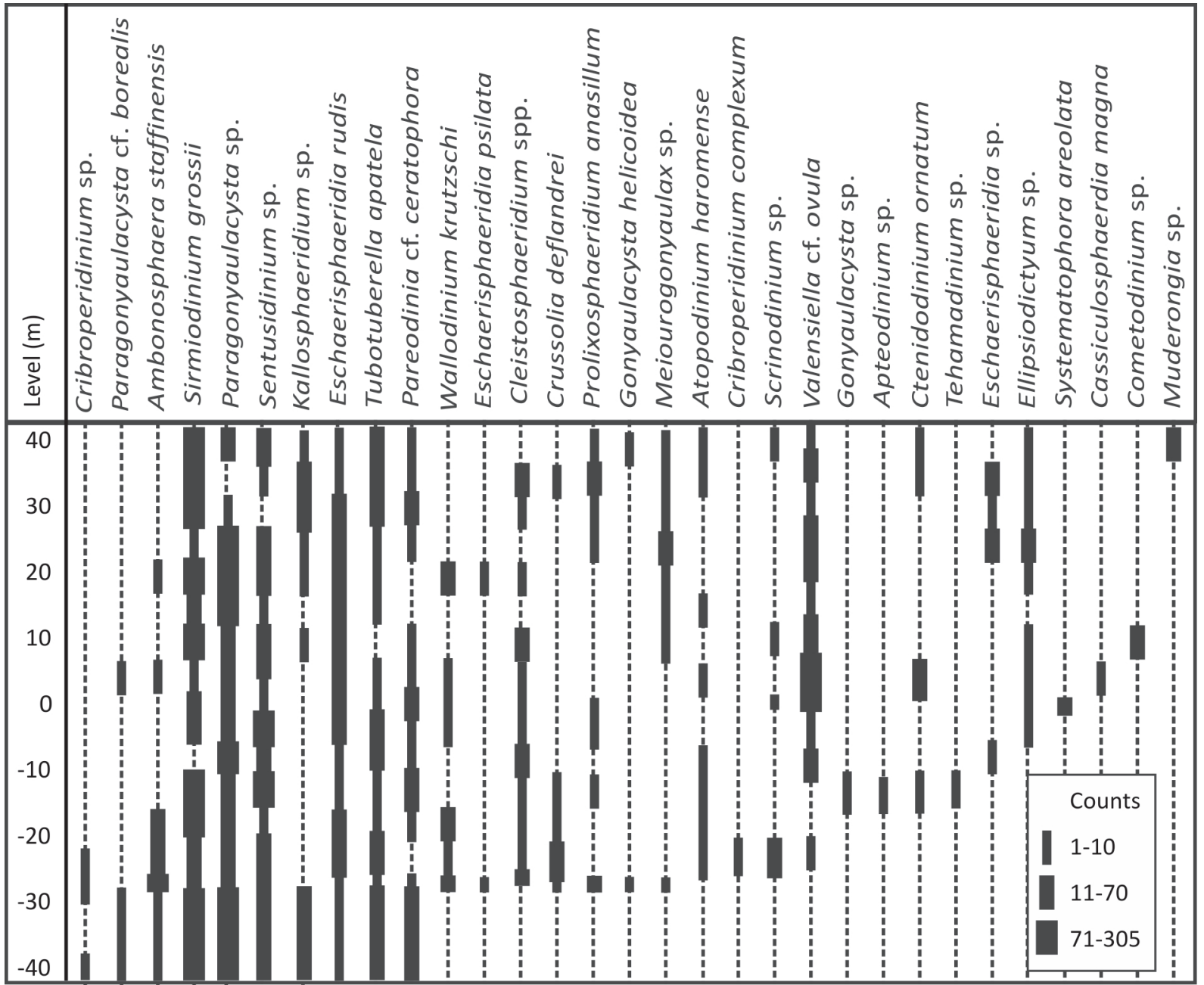

Figure 5. Stratigraphic and semi-quantitative distribution of dinoflagellate cyst taxa in the Slottsmøya Member at Knorringfjellet, Central Spitsbergen. The diagram is based on counts of approximately 300 specimens for most of the samples.

The seep samples are correlative with the upper shale samples of the Slottsmøya Member (Dalseg, 2012). Seep samples 2009-04 and 2009-03 from Janusfjellet are most correlative with the youngest shale samples. Seep sample 2007-01 from Knorringfjellet correlate to a lower degree with the shale samples (Fig. 6), as expected due to the larger age difference.

\section{Correlation of seep ammonites, foraminifera and dinoflagellate cysts}

The dinoflagellate cyst assemblages in the seep samples show a clear trend corresponding to the age assessment of the samples. The dinoflagellate cyst assemblages show largest similarities between samples 2009-03 and 200701 (Fig. 2). The NMDS graph (Fig. 6) shows that the dinoflagellate cyst assemblages in seep sample 2009-04 are most similar to the shale samples. This also correlates with the dating of the seeps (Fig. 2; Dalseg, 2012; Dalseg et al., in press). The two uppermost seep samples, of Late Ryazanian age, are of younger age than the uppermost shale sample (Nagy \& Basov, 1998; Hjálmarsdóttir et al., 2012). Seep sample 2009-04 correlates in age approximately with shale samples from $40 \mathrm{~m}$ and upwards.

\section{Environmental interpretations of the carbonate seep deposits in the Agardh- fjellet Formation}

Unlike hydrothermal vents, occurring in oceanic environments characterised by sea-floor spreading, cold methane seeps occur at continental margins and are characterised by relatively cold temperatures, similar to or slightly exceeding bottom water temperatures. The dominant hydrocarbon source is usually methane $\left(\mathrm{CH}_{4}\right)$ (Campbell, 2006; Blumenberg, 2010). The methane is oxidised and 


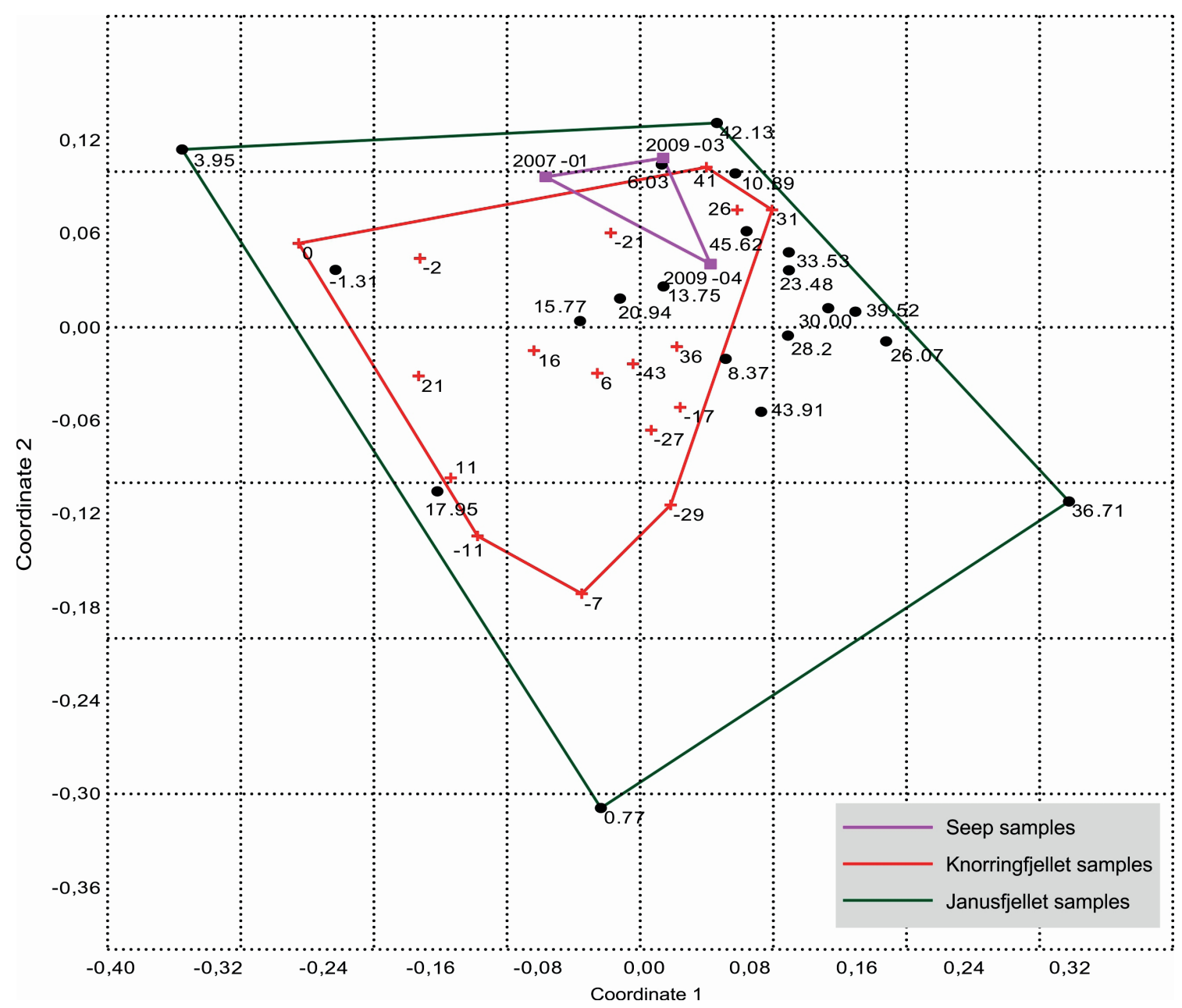

Figure 6. Non-metric Multidimensional Scaling (NMDS) of the dinoflagellate cysts in the carbonate seeps and the shales. The data are processed in PAST.

authigenic carbonate is precipitated within the sediment under anaerobic conditions. These conditions facilitate obligate sulphate-reducing bacteria and methanotrophic archaea. The hydrogen sulphide $\left(\mathrm{H}_{2} \mathrm{~S}\right)$ produced by these microorganisms is utilised by other thiotrophic bacteria (Magalhães et al., 2012). Seep ecosystems are found to commonly show low diversities and abundances. Some seep ecosystems, on the contrary, can show high diversities and abundances (Hammer et al., 2011).

The macrofaunas recovered from the seep carbonates are generally better preserved, more common and more diverse than the faunas found in the shales, siltstones and minor sandy beds comprising the bulk of the Agardhfjellet Formation. Hjálmarsdóttir et al. (2012), however, found that the assemblages of agglutinated benthic foraminifera in the hydrocarbon seep carbonates in the Agardhfellet Formation were comparable to the foraminifera faunas reported from the surrounding dark shales of the Slottsmøya Member.

In addition, the seep carbonate bodies contain ammonites, belemnites and large wood fragments representing ex situ fossils in these deposits (Hammer et al., 2011;
Wierzbowski et al., 2011). The organic-walled microfossils and palynodebris analysed in the present study also comprise ex situ fossil material in the seep deposits (Fig. 3 , Table 3). The palynomorphs consist of both specimens that originated during the time of deposition and fossils reworked from older strata.

Wierzbowski et al. (2011) and Hjálmarsdóttir et al. (2012) have previously described well preserved calcareous foraminifera and ammonites from the carbonate seep bodies in the Slottsmøya Member. Some of these carbonate deposits show high fossil abundances and high diversities, whereas most of the smaller carbonate seep bodies contain few fossils and show low diversities (Hammer et al., 2011).

Hryniewicz et al. (2012) pointed out that the seep carbonates in the upper part of the Slottsmøya Member were formed mainly within the sediment column, with only thin blankets of diverse deposits covering the surfaces of the seep carbonates. Most of the seeps were relatively small and short-lasting with carbonate hard-grounds developed on the surface, and only one long-lasting seep was covered with a blanket of worn grainy carbonate. 


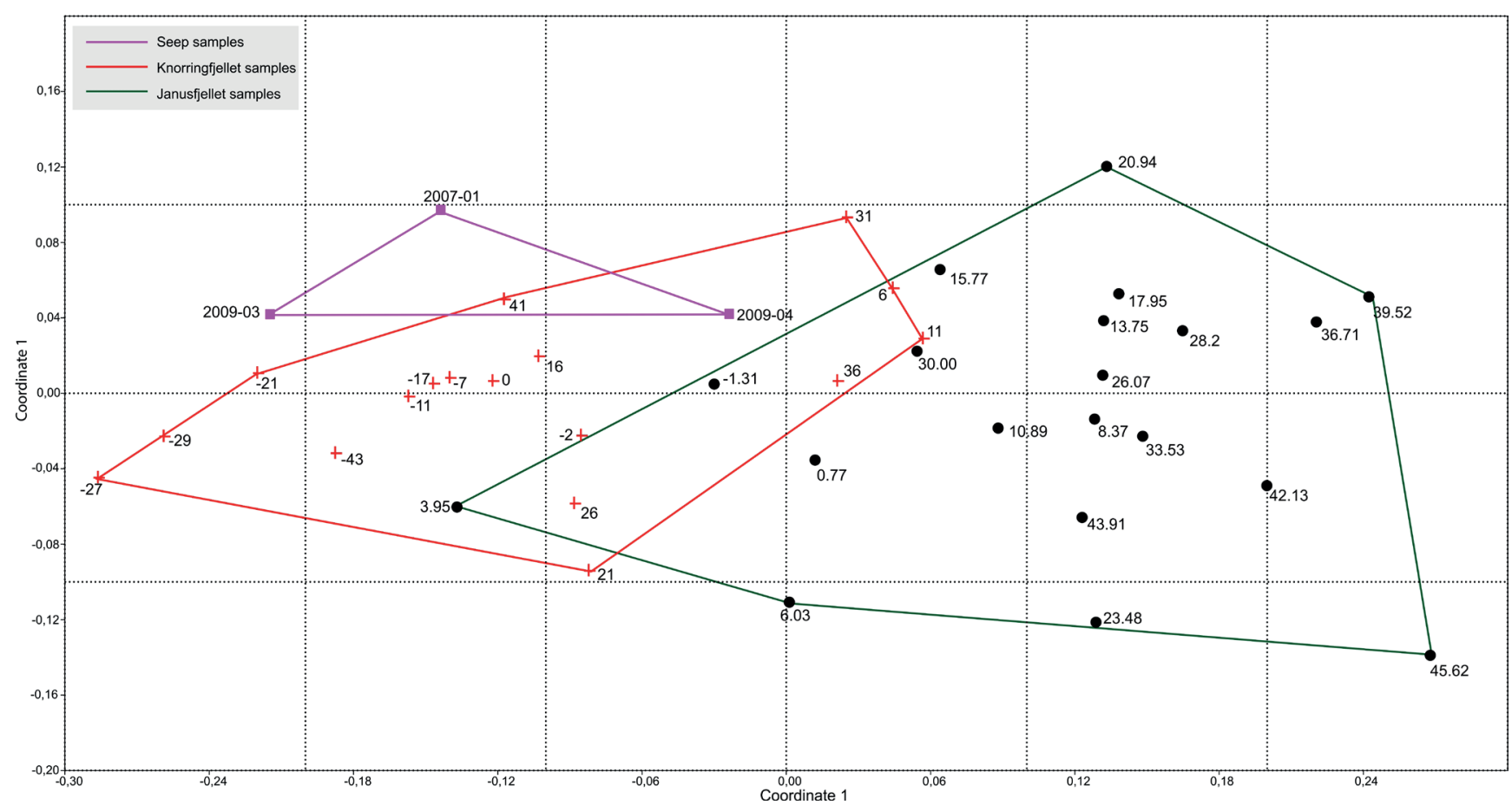

Figure 7. Non-metric Multidimensional Scaling (NMDS) of AOM, 'plant debris', wood, Leiosphaeridia, Tasmanites, dinoflagellate cysts, spores, bisaccate/monosaccate pollen, regular pollen and CFTL in the carbonate seeps and the shales. The data are processed in PAST.

According to Hryniewicz et al. (2012), the stratigraphic distribution of microfacies indicates a change in the original sediment from muds to more permeable silts and sands in the Late Ryazanian, probably caused by shallowing of the depositional environment. A depositional reconstruction of the seep environment, with a conceptual model, has recently been presented by Hryniewicz et al. (2015).

The palynological assemblages in all three carbonate seep samples in the present study show a much better preservation than the assemblages in the shale samples of the Slottsmøya Member. This is probably due to early authigenic precipitation of carbonate, which led to a relatively rapid cementation of the sediments, and thereby prevented flattening of the fossils (Hammer et al., 2011). Preservation of palynological assemblages can be influenced differently by the environment than by fossil groups consisting of other materials. This may be the case in the shale assemblages where vertebrate fossils found in the Slottsmøya Member generally are well preserved (Hurum et al., 2012), whereas agglutinated foraminiferans are much better preserved in the seep carbonates as compared with the shale occurrences (Hjálmarsdóttir et al., 2012). The shale assemblages in the present study show moderate to poor preservation. This is similar to what has previously been reported by Bjærke (1980) for the dinoflagellate cyst assemblages from the Upper Jurassic in Knorringfjellet.

\section{Comparisons between the palynofacies (palynodebris assemblages)}

The Non-metric Multidimensional Scaling (NMDS) of the palynofacies (Tables 1-3) shows that the palynodebris contents in the samples are more environmentally specific than age specific (Fig. 7). The carbonate seep samples show greatest similarities with the palynological assemblages in the lowermost shales in the Knorringfjellet profile. The environmentally dependent trend is expected as the dinoflagellate cyst assemblages are the only palynomorph group recognised to species level in the present study. The other palynomorphs are recognised only to higher taxonomic ranks, and do not show any changes through this relatively short time interval. The contents of sedimentary organic debris are mostly influenced by the environment and not evolution, and will therefore naturally not influence the trend when it comes to age.

Local currents around pockmarks have been studied by Hammer et al. (2009). Pockmarks are craters in the sea bed caused by erupting gases and fluids. By using threedimensional fluid dynamics, they found upstream convergence of flow lines followed by upwelling over the pockmark. This upwelling is only an effect of the deflected currents, and not of expulsion of fluid or gas from the sea floor. The effect of this is that more coarse-grained material is deposited in the pockmarks rather than in the surrounding areas (Hammer et al., 2009). This could be an explanation as to why all three seep samples investigated in the present study correspond so well with the samples from the lowermost part of the Knorringfjellet 
profile. This part of the Knorringfjellet profile generally consists of coarser material, and a higher energy regime has been suggested (Dypvik et al., 1991a, 1991b).

The plant debris is dominant in both the seep samples and the lower part of the Knorringfjellet profile (Dalseg, 2012; Dalseg et al., in press). This is not recorded in any of the other samples in the study. There is no significant difference in palynomorph content between the seep samples and the lower part of the Knorringfjellet profile or between these and other strata investigated, except for the absence of Tasmanites in the seep samples and in the lower part of the Knorringfjellet profile.

The low amount of amorphous organic matter (AOM) is the most obvious similarity between the seeps and the lower strata in the Knorringfjellet profile. This is possibly due to the relatively high-energy regime, and thus higher oxygen level, resulting in less degradation of material into AOM.

The diversities among the dinoflagellate cysts are highest in seep sample 2009-03. This sample also shows the lowest content of AOM of the three seep samples. This corresponds to the trends found in the shale samples. Sample 2009-03 also shows the highest content of 'plant debris' and the lowest content of wood and spores. In addition, this is the only seep sample with recorded chitinous foraminiferal test linings (CFTL). However, the percentage of the latter is low (1\%). The palynofacies contents indicate that the material in sample 2009-03 has been deposited under somewhat different environmental conditions than the material in the other two samples. The material in this sample may have been deposited in accordance with the sequence boundary proposed at $50 \mathrm{~m}$ in Collignon (2011).

The percentages of dinoflagellate cysts show a small decrease from the lowermost sample (2009-04) to the uppermost sample (2007-01), which correlate with the interpreted sea-level regression in the uppermost part of the Slottsmøya Member (Collignon, 2011). Two occurrences of the prasinophyte algae Cymatiosphaera sp. are recorded in sample 2009-04. This might also indicate a more distal location at this level (Sandersen, 2006). Hryniewicz et al. (2012) also proposed the possibility of a shallowing starting just before the latest Ryazanian.

The contents of bisaccate/monosaccate pollen and regular pollen are significantly higher in seep sample 2007-01 than in the other two samples. The higher content of the pollen groups in the uppermost seep sample (2007-01) probably reflects the shallowing of the sea. The regression in the Early Cretaceous, indicated by the coarsening interval in the top of the Slottsmøya Member (Collignon, 2011), would be expected to be followed by a higher amount of terrestrially derived AOM in carbonate seep samples 2007-01 and 2009-03. For all the seep samples in the present study, this number is approximately $70 \%$. An explanation may be a better preservation of plant debris, leading to a higher marine/terrestrial ratio in the AOM. A higher input of pollen and spores due to the relative sealevel regression is, however, somewhat in conflict with the higher proportion of marine constituents in the AOM.

Since dinoflagellates are primary producers, the high diversities and abundances of dinoflagellate cysts in the seep samples are probably a result of a high preservation potential (not a result of nutrients). Coarser material is deposited in the pockmarks rather than in the surrounding areas due to the dispersed currents above the pockmarks, as previously explained (Hammer et al., 2009). These currents may transport regular pollen and spores away from the pockmarks to a greater degree than the dinoflagellate cysts. This is based on the generally larger size of the dinoflagellate cysts observed in the present study.

The high diversity among the dinoflagellate cysts in the seep samples is possibly due to the high preservation potential of the seep assemblages. Samples 2009-04 and 2009-03 are from seep deposits which may have been developed in a condensed section (Hryniewicz et al., 2012). The high diversities in these seeps can thus also be a result of the greater degree of pelagic and hemi-pelagic settling.

\section{Conclusions}

The studied hydrocarbon seep carbonate deposits of the Slottsmøya Member (Agardhfjellet Formation) contain well preserved assemblages of organic-walled microfossils and palynodebris, representing ex situ fossil material in these deposits.

The palynomorphs from the Agardhfjellet Formation carbonate seep deposits in Central Spitsbergen, Svalbard, are better preserved than the palynological contents in the samples examined from the shale deposits in the same formation. This is due to early authigenic precipitation of carbonate, which led to a relatively rapid cementation of the sediments, thus preventing flattening of the fossils. The Non-metric Multidimensional Scaling (NMDS) of the dinoflagellate cyst assemblages in the studied succession shows an age-specific trend, rather than being environmentally controlled. The NMDS of the palynofacies shows that the contents of palynodebris in the samples are more environmental-specific than age-specific. The plant debris is significantly dominant in both the seep samples and the lower part of the Knorringfjellet shale-dominated profile. The low amount of AOM is the most prominent similarity between the seeps and the lower strata in the Knorringfjellet profile. This is possibly due to the relatively highenergy regime, and thus higher oxygen level, resulting in less degradation of material into AOM. The higher content of the pollen groups in the uppermost seep sample (2007$01)$ probably reflects a lowering of the sea level, as a sealevel fall in the Early Cretaceous is indicated by coarsening of the sediments in the top of the Slottsmøya Member. 
Acknowledgements. We acknowledge the Norwegian Research Council, Norwegian Petroleum Directorate, Spitsbergen Travel, ExxonMobil, Fugro, Statoil, OMV, Powercontrols and Hydro and the National Geographic Society for financing our fieldwork in the years 2007-2012. The authors are also grateful to all the volunteers and students from the Svalbard Jurassic Research Group for their participation in the joint fieldwork. Constructive comments on the manuscript by Henning Dypvik and an anonymous reviewer greatly improved the final paper.

\section{Reference list}

Beauchamp, B. \& Savard, M. 1992: Cretaceous chemosynthetic mounds in the Canadian Arctic. Palaios 7, 434-450.

Berndt, C., Feseker, T., Treude, T., Krastel, S., Liebetrau, V., Niemann, H., Bertics, V.J., Dumke, I., Dünnbier, K., Ferré, B., Graves, C., Gross, F., Hissmann, K., Hühnerbach, V., Krause, S., Lieser, K., Schauer, J. \& Steinle, L. 2014: Temporal constraints on hydrate-controlled methane seepage off Svalbard. Science 343, 284-287.

Bjærke, T. 1980: Mesozoic palynology of Svalbard V. Dinoflagellates from the Agardhfjellet Member (Middle and Upper Jurassic) in Spitsbergen. Norsk Polarinstitutt Skrifter 172, 145-167.

Blumenberg, M. 2010: Microbial chemofossils in specific marine hydrothermal and methane cold seep settings. In Kiel, S. (ed.): Vent and Seep Biota-Aspects from Microbes to Ecosystems, Topics in Geobiology 33, Springer, Germany, pp. 73-106.

Campbell, K.A. 2006: Hydrocarbon seep and hydrothermal vent paleoenvironments and paleontology: past developments and future research directions. Palaeogeography, Palaeoclimatology, Palaeoecology 232, 362-407.

Campbell, K.A., Farmer, J.D. \& Des Marais, D. 2002: Ancient hydrocarbon seeps from the Mesozoic convergent margin of California: carbonate geochemistry, fluids and palaeoenvironments. Geofluids 2, 63-94.

Chand, S., Mienert, J., Andreassen, K., Knies, J., Plassen, L. \& Fotland, B. 2008: Gas hydrate stability zone modeling in areas of salt tectonics and pockmarks of the Barents Sea suggests an active hydrocarbon venting system. Marine and Petroleum Geology 25, 625-636.

Chand, S. Thorsnes, T., Rise, L., Brunstad, H., Stoddart, D., Bøe, R., Lågstad, P. \& Svolsbru, T. 2012: Multiple episodes of fluid flow in the SW Barents Sea (Loppa High) evidenced by gas flares, pockmarks and gas hydrate accumulation. Earth and Planetary Science Letters 331-332, 305-314.

Collignon, M. 2011: Sedimentological analysis of the Slottsmøya Member, Agardhfiellet Formation (Late Jurassic- Early Cretaceous) in the Janusfiellet area, Spitsbergen. MSc thesis, University of Oslo, $31 \mathrm{pp}$.

Collignon, M.\& Hammer, Ø.2012: Lithostratigraphy and sedimentology of the Slottsmøya Member at Janusfjellet, Spitsbergen: evidence for a condensed section. Norwegian Journal of Geology 92, 89-101.

Dallmann, W.K., Major, H., Haremo, P., Andresen, A., Kjærnet, T. \& Nøttvedt, A. 2001: Geological map of Svalbard 1:100,000, sheet C9G Adventdalen. With explanatory text. Norsk Polarinstitutt Temakart 31/32, 4-55.

Dalseg, T.S. 2012: Palynological studies of the upper Oppdalsåta Member and the Slottsmøya Member (Agardhfiellet Formation), Upper Jurassic-Lower Cretaceous in Janusfjellet and Knorringfiellet, Central Spitsbergen. MSc thesis, University of Oslo, 107 pp.
Dalseg, T.S., Nakrem, H.A. \& Smelror, M. in press. Dinoflagellate biostratigraphy, palynofacies, depositional environment and sequence stratigraphy of the Agardhfjellet Formation (Upper Jurassic-Lower Cretaceous) in Central Spitsbergen (Arctic Norway). Norwegian Journal of Geology.

Dypvik, H., Eikeland, T.A., Backer-Owe, K. \& Johansen, H. 1991a: Depositional conditions of the Bathonian to Hauterivian Janusfellet Subgroup, Spitsbergen. Sedimentary Geology 72, 55-78.

Dypvik, H., Nagy, J., Eikeland, T.A., Backer-Owe, K. Andresen, A., Haremo, P., Bjærke, T., Johansen, H. \& Elverhøi, A. 1991b: The Janusfjellet Subgroup (Bathonian \& Hauterivian) on central Spitsbergen: A revised lithostratigraphy. Polar Research 9, 21-43.

Hammer, Ø., Harper, D.A.T. \& Ryan, P.D. 2001: PAST: Palaeontological statistics software package for education and data analysis. Palaeontologia Electronica 4, 9 pp.

Hammer, Ø., Webb, K.E. \& Depreiter, D. 2009: Numerical simulation of upwelling currents in pockmarks, and data from the Inner Oslofjord, Norway. Geo-Marine Letters 29, 269-275.

Hammer, Ø., Nakrem, H.A., Little, C.T.S., Hryniewicz, K., Sandy, M.R., Hurum, J.H., Druckenmiller, P., Knutsen, E.M. \& Høyberget, M. 2011: Hydrocarbon seeps from close to the Jurassic-Cretaceous boundary, Svalbard. Palaeogeography, Palaeoclimatology, Palaeoecology 306, $15-26$.

Hammer, Ø., Collignon, M. \& Nakrem, H.A. 2012: Organic carbon isotope chemostratigraphy and cyclostratigraphy in the Volgian of Svalbard. Norwegian Journal of Geology 92, 103-112.

Hammer, Ø., Hryniewicz, K., Hurum, J.H., Høyberget, M., Knutsen, E.M. \& Nakrem, H.A. 2013: Large onychites (cephalopod hooks) from the Upper Jurassic of the Boreal Realm. Acta Palaeontologica Polonica 58, 827-835.

Hjálmarsdóttir, H.R., Nakrem, H.A. \& Nagy, J. 2012: Foraminifera from Late Jurassic - Early Cretaceous hydrocarbon seep carbonates, central Spitsbergen, Svalbard - preliminary results. Norwegian Journal of Geology 92, 157-165.

Holmer, L.E. \& Nakrem, H.A. 2012: The lingulid brachiopod Lingularia from lowermost Cretaceous hydrocarbon seep bodies, Sassenfjorden area, central Spitsbergen, Svalbard. Norwegian Journal of Geology 92, 167-174.

Hovland, M. \& Svendsen, H. 2006: Submarine pingoes: Indicators of shallow gas hydrates in a pockmark at Nyegga, Norwegian Sea. Marine Geology 228, 15-23.

Hryniewicz, K., Hammer, Ø., Nakrem, H.A. \& Little, C.T.S. 2012: Microfacies of the Volgian-Ryazanian (Jurassic-Cretaceous) hydrocarbon seep carbonates from Sassenfjorden, central Spitsbergen, Svalbard. Norwegian Journal of Geology 92, 113-131.

Hryniewicz, K., Little, C.T.S. \& Nakrem, H.A. 2014: Bivalves from the latest Jurassic-earliest Cretaceous hydrocarbon seep carbonates from central Spitsbergen, Svalbard. Zootaxa 3859, 1-66.

Hryniewicz, K., Nakrem, H.A., Hammer, Ø., Little, C.T.S., Kaim, A., Sandy, M. \& Hurum, J.H. 2015: The palaeoecology of latest Jurassicearliest Cretaceous hydrocarbon seep carbonates from Spitsbergen, Svalbard. Lethaia 48, 353-374. doi: 10.1111/let.12112.

Hurum, J.H., Nakrem, H.A., Hammer, Ø., Knutsen, E.M., Druckenmiller, P.S., Hryniewicz, K. \& Novis, L.K. 2012: An Arctic Lagerstätte - the Slottsmøya Member of the Agardhfjellet Formation (Upper Jurassic - Lower Cretaceous) of Spitsbergen. Norwegian Journal of Geology 92, 55-64.

Kauffman, E.G., Arthur, M.A., Howe, B. \& Scholle, P.A. 1996: Widespread venting of methane-rich fluids in Late Cretaceous (Campanian) 
submarine springs (Tepee Buttes), Western Interior seaway, U.S.A. Geology 24, 799-802.

Kelly, S.R.A., Ditchfield, P.W., Doubleday, P.A. \& Marshall, J.D. 1995: An Upper Jurassic methane-seep limestone from the Fossil Bluff Group forearc basin of Alexander Island, Antarctica. Journal of Sedimentary Research 65, 274-282.

Kiel, S., Amano, K. \& Jenkins, R.G. 2008: Bivalves from Cretaceous coldseep deposits on Hokkaido. Japan. Acta Palaeontologica Polonica 53, 525-537.

Levin, L.A. 2005: Ecology of cold seep sediments: interactions of fauna with flow, chemistry and microbes. Oceanography and Marine Biology: An Annual Review 43, 1-46.

MacDonald, I.R., Guinasso, Jr., N.L., Sassen, R., Brooks, J.M., Lee, L. \& Scott, K.T. 1994: Gas hydrate that breaches the sea floor on the continental slope of the Gulf of Mexico. Geology 22, 699-702.

Magalhães, V.H., Pinheiro, L.M., Ivanov, M.K., Kozlova, E., Blinova, V., Kolganova, J., Vasconcelos, C., McKenzie, J.A., Bernasconi, S.M., Kopf, A.J., Díaz-del-Río, V., González, F.J. \& Somoza, L. 2012: Formation processes of methane-derived authigenic carbonates from the Gulf of Cadiz. Sedimentary Geology 243-244, 155-168.

Mørk, A., Dallmann, W.K., Dypvik, H., Johannessen, E.P., Larssen, G.B., Nagy, J., Nøttvedt, A., Olaussen, S., Pčelina, T.M. \& Worsley, D. 1999: Mesozoic lithostratigraphy. In Dallmann, W.K. (ed.): Lithostratigraphic lexicon of Svalbard. Upper Palaeozoic to Quaternary bedrock. Review and recommendations for nomenclature use, Norsk Polarinstitutt, Tromsø, pp. 127-214.

Naehr, T.H., Rodriguez, N.M., Bohrmann, G., Paull, C.K. \& Botz, R. 2000: Methane-derived authigenic carbonates associated with gas hydrate decomposition and fluid venting above the Blake Ridge Diapir. In Paull, C.K., Matsumoto, R. \& Wallace, P.J. (eds.): Proceedings of the Ocean Drilling Program, Scientific Results 164, pp. 285-300.

Nagy, J. \& Basov, V.A. 1998: Revised foraminifera taxa and biostratigraphy of Bathonian to Ryazanian deposits in Spitsbergen. Micropaleontology 44, 217-255.

Ogg, J.G. \& Hinnov, L.A. 2012. Jurassic and Cretaceous. In Gradstein, F.M., Ogg, J.G., Schmitz, M.D. \& Ogg, G.M. (eds.): The Geologic Time Scale 2012, Elsevier B.V., Amsterdam, pp. 731-792 and 793854.

Paull, C.K., Hecker, B., Commeau, R., Freeman-Lynde, R.P., Neumann, A.C., Corso, W.P., Golubic, S., Hook, J., Sikes, E. \& Curray, J. 1984: Biological communities at Florida Escarpment resemble hydrothermal vent communities. Science 226, 965-967.

Ritger, S., Carson, B. \& Suess, E. 1987: Methane-derived authigenic carbonates formed by subduction-induced pore-water expulsion along the Oregon/Washington margin. Geological Society of America Bulletin 98, 147-156.

Sandersen, A. 2006: A palynological investigation of the offshore Cretaceous sequence on the south-west coast of South Africa Volume 1-2. Dr. philos. thesis, University of Witwatersrand, Johannesburg, $568 \mathrm{pp}$.

Sandy, M., Hryniewicz, K., Hammer, Ø., Nakrem, H.A. \& Little, C.T.S. 2014: Brachiopods from Late Jurassic - Early Cretaceous hydrocarbon seep deposits, central Spitsbergen, Svalbard. Zootaxa $3884,32 \mathrm{pp}$.

Sassen, R., Roberts, H.H., Aharon, P., Larkin, J., Chinn, E.W. \& Carney, R. 1993: Chemosynthetic bacterial mats at cold hydrocarbon seeps, Gulf of Mexico continental slope. Organic Geochemistry 20, 77-89.

Wierzbowski, A., Hryniewicz, K., Hammer, Ø., Nakrem, H.A. \& Little, C.T.S. 2011: Ammonites from hydrocarbon seep carbonate bodies from the uppermost Jurassic - lowermost Cretaceous of Spitsbergen, Svalbard, and their biostratigraphic importance. Neues Jahrbuch für Geologie und Paläontologie 262, 267-288. 